\title{
Kualitas Dedak dari Berbagai Varietas Padi di Bengkulu Utara
}

\author{
Rice brand quality of several rice varieties In North Bengkulu \\ Tris Akbarillah, Hidayat dan Tuti Khoiriyah \\ Jurusan Peternakan Fakultas pertanian UNIB \\ Jalan Raya Kandang Limun Bengkulu, telp. (0736) 21170. Pst. 219.
}

\begin{abstract}
Ricebrand is crop by-product commonly used as feedstuff. Rice brand has various qualities depending on its variety. The quality of the rice brand is showed by its nutritive value.The research was done as long as 1 month, started April $15^{\text {th }}$ to May $14^{\text {th }} 2005$. The rice brand was collected from Kemumu, Tanjung Harapan and Margasakti village in North Bengkulu. Moisture, ash, ether extract, crude fiber, and gross energy content were analyzed at laboratory of animal nutrition Bengkulu University. In addition, crude protein was analyzed at laboratory of nutrition Muhammadiyah University Malang.The experiment design used was a completely randomized design, consisted of three treatments, with three replicates. The treatments were P1: rice brand IR-64 variety, P2: rice brand IR-66 variety and P3: rice brand Ciliwung variety.Variables observed were moisture, ash, ether extract, crude fiber, metabolisble energy, and crude protein content. The data were then analyzed of variance; the significant result was tested by Duncan't Multiple Range test.The result showed that variety of rice affects quality of rice brand produced. Based on their nutritive value, variety of IR-64 resulted best quality compared to IR-66 and Ciliwung. IR-64 showed low CF (14.62\%), high CP (11.01\%), high ME $(2466.35 \mathrm{KKal} / \mathrm{Kg})$, ash $(10.88 \%)$, EE $(8.57 \%)$, NFE (54.95\%), and DM $(88.63 \%)$. In conclution, the quality (nutritive value) of rice brand was affected by variety of rice
\end{abstract}

Key words : Ricebrand by product, varietas, Proximate analized.

\begin{abstract}
ABSTRAK
Dedak padi merupakan limbah pengolahan padi menjadi beras dan kualitasnya bermacam-macam tergantung dari varietas padi. Tujuan penelitian untuk mengetahui kualitas dedak padi dari berbagai varietas padi yang ditanam petani di Bengkulu Utara. Penelitian dilaksanakan pada tanggal 15 April sampai 14 Mei 2005, sampel diperoleh dari desa Kemumu Kecamatan Argamakmur dan desa Tanjung Harapan maupun desa Margasakti Kecamatan Padangjaya. Digunakan rancangan acak lengkap (RAL) dengan menggunakan 3 varietas padi dan masing-masing perlakuan diulang 3 kali. P1 : dedak padi varietas IR-64, P2 : dedak padi varietas IR-66 dan P3 : dedak padi varietas Ciliwung. Sampel di analisis proksimat meliputi kadar air, bahan kering, lemak kasar, serat kasar, kadar abu, BETN dan energi termetabolis dilakukan di Laboratorium Jurusan Peternakan Universitas Bengkulu, dan analisis protein kasar dilakukan di Laboratorium Nutrisi Universitas Muhammadiyah Malang. Data yang diperoleh dianalisis sidik ragam, bila terdapat pengaruh yang nyata diuji dengan Duncant Multiple Range Test (Stell and Torrie, 1991). Variabel yang diamati adalah pengamatan fisik dedak padi, kadar air, bahan kering, kadar abu, serat kasar, lemak kasar, protein kasar, BETN, Energi termetabolis. Hasil penelitian menunjukkan bahwa Varietas berpengaruh sangat nyata $(\mathrm{P}<0,01)$ terhadap komposisi kimia dedak padi, tapi tidak berpengaruh $(\mathrm{P}>0,05)$ terhadap tampilan fisiknya. Kualitas dedak padi termasuk baik adalah varietas padi IR-64 dan mengandung serat kasar terrendah sebesar 14,62\%, protein kasar: 11,01\%, energi termetabolis sebesar 2466,35 kkal/kg, kadar abu sebesar 10,88 \%, lemak kasar sebesar $8,57 \%$, BETN sebesar 54,95\% dan bahan kering sebesar $88,63 \%$. Sedangkan dedak padi dengan kualitas sedang adalah dedak padi dari varietas Ciliwung dan dedak padi dengan kualitas rendah adalah dedak padi dari varietas IR-66, hal tersebut dikarenakan mempunyai serat kasar tinggi, protein dan energi termetabolis rendah.Hasil penelitian dapat disimpulkan bahwa dedak padi dengan varietas IR-64 mempunyai kualitas baik mengandung serat kasar terrendah, energi termetabolis tertinggi dan protein kasar tinggi. Dedak padi dengan kualitas sedang adalah dedak padi dari varietas Ciliwung dan dedak padi dari varietas IR-66 mempunyai kualitas yang rendah karena kandungan gizinya. Dari hasil penelitian ini membuktikan bahwa varietas padi mempengaruhi kualitas dedak padi sebagai hasil ikutannya.
\end{abstract}

Kata Kunci: dedak padi, varietas, analisa proksimat. 


\section{PENDAHULUAN}

Hasil sampingan proses pengolahan padi adalah dedak padi (rice brand). Bahan ini dihasilkan dalam tahapan-tahapan proses pengupasan kulit gabah dan penyosohan beras pecah kulit. Bengkulu Utara merupakan penghasil dedak.sebagai byproduct penggilingan padi menjadi beras. Varietas yang ditanam oleh petani di daerah tersebut meliputi : varietas IR-64, varietas IR-66 dan varietas Ciliwung yang ditanam dengan sistim pengairan (sawah). Varietas yang berbeda, mempunyai kondisi fisik yang berbeda sehingga mengakibatkan derajat kerapuhan, derajat kerusakan, kadar air yang berbeda. Keadaan ini juga mengakibatkan mutu dedak sebagai bahan ikutan yang dihasilkan berbedabeda. Untuk mengetahui kualitas dedak dari varietas yang berbeda selain pengamatan fisik juga perlu dilakukan analisis komposisi kimianya.Butir padi atau gabah terdiri atas bagian yang dapat dimakan disebut caryopsis atau beras, dan satu bagian lagi merupakan kulitnya, yang disebut sekam yang menempati 18 - 28\% dari bobot padi (Juliano, 1972 dalam Yudono, 1996). Menurut Yudono (1996) proses penggilingan padi dapat menghasilkan beras giling sebanyak 65\% dan limbah hasil gilingan sebanyak 35\%, yang terdiri dari sekam 23\%, dedak dan bekatul sebanyak $10 \%$.

Varietas merupakan salah satu faktor yang menentukan kualitas dedak, karena kandungan protein dan serat kasar ditentukan oleh keragaman sifat fisik dan sifat kimia gabah terutama disebabkan oleh faktor genetik yang dibawa oleh varietas padi (Ishaq $d k k$., 2001). Kanro (2000) menyatakan bahwa hasil suatu tanaman ditentukan oleh faktor genetik, faktor lingkungan, dan interaksi faktor lingkungan dan faktor genetik. Kesuburan tanah merupakan faktor yang menentukan jumlah produksi gabah. Apabila kesuburan tanah sesuai dengan media tumbuh padi maka akan menghasilkan produksi dan kualitas (komposisi kimia) dedak yang baik (Indranada, 1994; Ishaq $d k k, 2001)$. Tampilan fisik dedak padi dipengaruhi penggilingan ataupun pengolahan saat pengeringan gabah. Hal ini dapat mengakibatkan kualitas dedak yang didapat nantinya beragam (Rasyaf,
1990). Pemeriksaan fisik dedak adalah dilakukan melalui baunya, bau tengik atau bau tidak normal pertanda dedak mulai rusak, bila berwarna coklat terang adalah baik tetapi bila sudah berwarna keputih-putihan atau kehijauhijauan pertanda dedak itu sudah rusak (Rasyaf, 1990).

Besarnya kadar air/ bahan kering dedak padi adalah 8\%-14\%/86\%-92\% (Hartadi et al, 1997; Zuprizal, 2000).), Ekstrak eter dedak padi adalah 5\%-13\% (Hartadi et al., 1997), lebih rendah dibanding penelitian Zuprial (2000), yaitu 10\%-20\%. Besarnya protein kasar dedak padi adalah 8\%-14\% (Hartadi, 1997; Zuprizal, 2000).. Besarnya serat kasar dedak padi adalah 6\%-30\% (Hartadi, 1997; Zuprizal, 2000). Besarnya kadar abu dedak padi adalah 5\%16\% (Hartadi, 1997; Zuprizal, 2000). BETN dedak padi adalah $23 \%-70 \%$ Hartadi et al (1997), hasil ini lebih tinggi dari Zuprizal (2000) yaitu 37\%-68\%. Besarnya energi termetabolis dedak padi adalah $2998 \mathrm{kcal} / \mathrm{kg}$ $3498 \mathrm{Kcal} / \mathrm{kg}$ Hartadi et al (1997). Hasil tersebut lebih tinggi dari Zuprizal (2000) yaitu 2500,76 $\mathrm{kcal} / \mathrm{kg}-2840,23 \mathrm{kcal} / \mathrm{kg}$.

\section{MATERI DAN METODE}

Penelitian ini dilaksanakan pada tanggal 15 April 2005 sampai tanggal 14 Mei 2005 selama 1 bulan. Pengambilan sampel diperoleh dari 3 desa di Kecamatan Padangjaya, Kabupaten Bengkulu Utara. Analisis proksimat yang meliputi kandungan bahan kering, serat kasar, lemak kasar, abu, BETN /Bahan Ekstrak Tanpa Nitrogen (Anggorodi, 1979 ; Tillman et al., 1998) dan Energi Termetabolis (Men) dengan menggunakan rumus Energi Pakan. Analisis proksimat selain protein kasar dilaksanakan di Laboratorium Jurusan Peternakan Fakultas Pertanian Universitas Bengkulu. Analisis protein kasar dilaksanakan di Laboratorium Nutrisi Universitas Muhammadiyah Malang. Alat yang digunakan meliputi kantung, timbangan analitik, alat-alat untuk analisis proksimat , karung. Bahan yang digunakan adalah dedak padi dari 3 varietas yaitu IR-64, IR-66, dan Ciliwung, serta larutan untuk analisis proksimat. Sampel penelitian diambil berupa gabah per masing-masing varietas, merupakan 
varietas yang banyak ditanam dan lokasi pengambilan sampel adalah daerah padi (sumber beras). Sampel diambil masingmasing desa sebanyak $30 \mathrm{~kg}$ gabah kering dengan 3 ulangan. Kapasitas mesin huller adalah minimal $30 \mathrm{~kg}$ gabah. Gabah digiling disatu huller. Dedak diamati tampilan phisik dan komposisi kimia (analisis proksimat ) Penelitian ini menggunakan RAL (Rancangan Acak Lengkap) dengan tiga perlakuan (P1 : Dedak padi varietas IR-64,P2 : Dedak padi varietas IR-66 dan P3 : Dedak padi varietas Ciliwung). Data yang diperoleh dianalisis dengan sidik ragam (ANOVA) bila terdapat pengaruh yang nyata, dilanjutkan uji Duncant Multiple Range Test (Stell dan Torrie, 1991).Variabel yang diamati meliputi pengamatan phisik warna, bau dan kehalusan partikel dan komposisi kimia kadar air, bahan kering, kadar abu, serat kasar, ekstrak eter, protein kasar dan BETN serta energi metabolis
(MEn) dihitung dengan menggunakan persamaan $\mathrm{MEn}_{n}=46,70 \times \mathrm{BK}-46,70 \times \mathrm{Abu}-$ 69,54 x PK + 42,9 x EE - 81,95 x SK (Janssen et al., 1979 dalam NRC, 1994 MEn untuk rice brand)

\section{HASIL DAN PEMBAHASAN}

\section{Tampilan fisik}

Berdasarkan hasil pengamatan, varietas dedak padi yang berbeda tidak memberikan perbedaan tampilan fisiknya.. Berdasarkan kasap mata dapat dilihat bahwa warna dari dedak IR 64, IR 66 dan Ciliwung berwarna coklat terang., bau harum (tidak tengik) (Rasyaf ,1990). Tampilan partikel dedak semua varietas padi hasil penelitian ini tergolong halus.. Varietas yang berbeda tidak menampakan perbedaan penampilan partikel secara kasap mata.

Tabel 1. Hasil pengamatan fisik dedak padi dengan varietas yang berbeda

\begin{tabular}{|c|c|c|c|c|c|c|c|c|c|}
\hline Parameter & P1U1 & P1U2 & P1U3 & P2U1 & P2U2 & P2U3 & P3U1 & P3U2 & P3U3 \\
\hline Warna & $\begin{array}{l}\text { Coklat } \\
\text { terang }\end{array}$ & $\begin{array}{l}\text { Coklat } \\
\text { terang }\end{array}$ & $\begin{array}{l}\text { Coklat } \\
\text { terang }\end{array}$ & $\begin{array}{l}\text { Coklat } \\
\text { terang }\end{array}$ & $\begin{array}{l}\text { Coklat } \\
\text { terang }\end{array}$ & $\begin{array}{l}\text { Coklat } \\
\text { terang }\end{array}$ & $\begin{array}{l}\text { Coklat } \\
\text { terang }\end{array}$ & $\begin{array}{l}\text { Coklat } \\
\text { terang }\end{array}$ & $\begin{array}{l}\text { Coklat } \\
\text { Terang }\end{array}$ \\
\hline Bau & Harum & Harum & Harum & Harum & Harum & Harum & Harum & Harum & Harum \\
\hline $\begin{array}{c}\text { Tampilan } \\
\text { partikel }\end{array}$ & Halus & Halus & Halus & Halus & Halus & Halus & Halus & Halus & Halus \\
\hline
\end{tabular}

\section{Komposisi kimia (kandungan gizi)}

Hasil sidik ragam menunjukkan bahwa varietas padi berpengaruh sangat nyata
$(\mathrm{P}<0,01)$ terhadap kadar air. Hasil uji lanjut kadar air P1 paling tinggi. Hasil penelitian ini lebih rendah yang dilaporkan Hartadi et al., (1997) yaitu sebesar 14\%. Bahan kering nilainya bervariasi antara $88,63 \%$ sampai $90,13 \%$.

Tabel 2. Rataan hasil analisis kandungan gizi perlakuan

\begin{tabular}{lcccccc}
\hline \multicolumn{1}{c}{ Komposisi kimia } & P1 & \multicolumn{5}{c}{ P2 } \\
\cline { 2 - 6 } & Segar & DM & Segar & DM & Segar & DM \\
\hline Bahan Kering (\%) & $88,63^{\mathrm{c}}$ & 100 & $90,13^{\mathrm{a}}$ & 100 & $89,17^{\mathrm{b}}$ & 100 \\
Kadar air (\%) & $11,37^{\mathrm{a}}$ & 0 & $9,87^{\mathrm{c}}$ & 0 & $10,83^{\mathrm{b}}$ & 0 \\
Kadar abu (\%) & 9,65 & $10,88^{\mathrm{c}}$ & 12,10 & $13,42^{\mathrm{a}}$ & 10,16 & $11,39^{\mathrm{b}}$ \\
Serat Kasar (\%) & 12,95 & $14,62^{\mathrm{c}}$ & 17,60 & $19,53^{\mathrm{a}}$ & 14,27 & $15,99^{\mathrm{b}}$ \\
Lemak Kasar (\%) & 7,60 & $8,57^{\mathrm{a}}$ & 5,50 & $6,10^{\mathrm{c}}$ & 6,80 & $7,62^{\mathrm{b}}$ \\
Protein Kasar (\%) & 9,76 & $11,01^{\mathrm{ab}}$ & 9,02 & $10,01^{\mathrm{b}}$ & 11,07 & $12,41^{\mathrm{a}}$ \\
BETN (\%) & 48,67 & $54,95^{\mathrm{a}}$ & 45,90 & $50,93^{\mathrm{b}}$ & 46,86 & $52,56^{\mathrm{b}}$ \\
Energi Termetabolis & & & & & & \\
(KKal/Kg) & 2185,92 & $2466,35^{\mathrm{a}}$ & 1720,12 & $1908,38^{\mathrm{c}}$ & 1953,26 & $2190,42^{\mathrm{b}}$ \\
\hline
\end{tabular}


a,b,c :Superskrip yang berbeda pada baris yang sama menunjukkan perbedaan yang sangat nyata ( $\mathrm{P}<0,01)$. P1: Dedak padi varietas IR-64, P2: Dedak padi varietas IR-66, P3: Dedak padi Varietas Ciliwung. DM (Dry Matter) atas dasar Bahan Kering

Kandungan bahan kering menunjukan perbedaan sangat nyata $(\mathrm{P}<0,01)$. Uji lanjut menunjukan kandungan bahan kering pada perlakuan P1 berbeda sangat nyata dengan perlakuan P2 dan P3. Kandungan bahan kering dari penelitian ini relatif lebih tinggi dari yang dilaporkan Hartadi et al., (1998), yaitu sebesar $86 \%$. sedangkan menurut Zuprizal (2000) sebesar 89,76. Kadar abu menunjukkan perbedaan sangat nyata $(\mathrm{P}<0,01)$.

Hasil uji lanjut menunjukkan bahwa kadar abu perlakuan P1 adalah terendah. Kadar abu dedak padi IR-64 lebih rendah dibandingkan IR-66 dan Ciliwung.Hasil ini lebih tinggi dari Hartadi et al., 1997 dan lebih rendah Zuprizal (2000) bahwa tingginya kandungan abu dalam dedak padi diduga karena banyak mengandung sekam, yang mengandung banyak silica. Varietas padi yang berbeda menyebabkan kadar abu dedak berbeda. Kadar serat kasar berdasarkan anova menunjukkan bahwa varietas berpengaruh sangat nyata $(\mathrm{P}<0,01)$ terhadap kadar serat kasar. Serat kasar terendah pada dedak padi IR 64. Kadar lemak kasar berdasarkan sidik ragam menunjukkan perbedaan sangat nyata $(\mathrm{P}<0,01)$. Hasil uji lanjut menunjukkan bahwa perlakuan P1 (IR 64) tertinggi. Kandungan lemak kasar yang di dapat dari penelitian lebih rendah dari yang dilaporkan Hartadi et al., (1997), yaitu $12 \%-13,80 \%$. Tingginya kandungan lemak kasar akan menyebabkan dedak padi menjadi lebih mudah tengik yang disebabkan terbebasnya asam lemak oleh adanya enzim lipolitik yang menjadi aktif saat pemisahan dari beras (Zuprizal, 2000). Kadar serat kasar berdasarkan hasil sidik ragam menunjukkan bahwa varietas berpengaruh sangat nyata $(\mathrm{P}<0,01)$ terhadap kadar serat kasar. Hasil uji lanjut menunjukkan bahwa P1 terrendah. Nilai kandungan serat kasar ditentukan dari keragaman sifat fisik dan kimia gabah terutama disebabkan oleh faktor genetik yang dibawa oleh masing-masing varietas. Hal ini sesuai dengan Damardjati (1982) dalam Ishaq (2001) bahwa keragaman sifat fisik gabah disebabkan terutama oleh faktor genetik yang dibawa oleh masing- masing varietas. Dedak padi pada penelitian ini termasuk pada golongan dedak padi halus dengan serat kasar berkisar antara 9\% - 18\% (P1: 14,62\% dan P3: 15,99\%), bila kandungan serat kasar $>18 \%$ tergolong dedak kasar maka P2 varietas IR-66 tergolong dedak kasar dengan serat kasar sebesar 19,53\% Zuprizal (2000). Kadar protein kasar menunjukkan pengaruh nyata $(\mathrm{P}<0,05)$ terhadap protein kasar. Hasil uji lanjut perlakuan P1 berbeda tidak nyata dengan perlakuan P2 dan P3 dan perlakuan P2 berbeda nyata dengan P3, perlakuan P1 dan P3 juga tidak berbeda nyata. Hasil penelitian ini relatif rendah dibanding penelitian Zuprizal (2000). Varietas berpengaruh sangat nyata terhadap kadar protein kasar dedak padi (Ishaq, (2001), BETN berdasarkan hasil sidik ragam menunjukkan perlakuan berpengaruh nyata $(\mathrm{P}<0,05)$ terhadap BETN. Hasil uji lanjut, kadar BETN pada perlakuan P1 berbeda nyata dengan perlakuan P2 dan P3, dan P2 berbeda tidak nyata dengan P3. P1 nyata lebih tinggi di banding P2 dan P3. Hasil penelitian ini relatif rendah dari penelitian Hartadi (1997) dan Zuprizal (2000). Besar kecilnya kandungan BETN berkaitan dengan besarnya kandungan serat kasar. (Tilman et al., 1998). Energi Termetabolis berdasarkan hasil sidik ragam menunjukkan perlakuan berpengaruh sangat nyata $(\mathrm{P}<0,01)$ terhadap Energi Termetabolis. Hasil uji lanjut, Energi Termetabolis perlakuan P1 nyata lebih tinggi dibanding perlakuan P2 dan P3. Hasil penelitian ini lebih rendah dari Hartadi et al., 1997 dan Zuprizal.,2000. Varietas padi berpengaruh terhadap energi termetabolis dedak padi

\section{SIMPULAN}

Dedak padi varietas IR-64 mempunyai kualitas yang baik. mempunyai kandungan serat kasar paling rendah, energi tertinggi dan memiliki protein cukup tinggi. Dedak padi dengan kandungan protein kasar tertinggi adalah padi varietas Ciliwung. Dedak padi dari varietas IR-66 mempunyai kualitas terrendah. Dari hasil penelitian ini 
membuktikan bahwa varietas padi mempengaruhi kualitas dedaknya.

\section{DAFTAR PUSTAKA}

Anggorodi, R. 1979. Ilmu Makanan Ternak Umum. Gramedia Pustaka. Jakarta.

Hartadi, H. , S. Reksohadiprojo, A. D. Tilman. 1997. Tabel Komposisi Pakan Untuk Indonesia. Cetakan Keempat. Gadjah Mada University Press.Yogyakarta.

Indranada. H. 2000. Pengelolaan kesuburan tanah. Penebar swadaya. Jakarta

Ishaq, A. Arifin Amril, M. dan Nancy Lahay. 2001. Pengaruh jenis penggilingan dan varietas padi terhadap kandungan protein dan serat kasar dedak padi yang telah mengalami penyimpanan satu bulan. Buletin Nutrisi dan Makanan Ternak, Vol 2 (2). 55 - 63.

NRC. 1994. Nutrient Requirements Of Poultry. Ninth Revised Edition National Academy Press. Washington, D. C. , USA.
Rasyaf, M. 1990. Bahan Makanan Unggas di Indonesia. Kanisius. Yogyakarta.

Ravindran. V dan R. Blair. Feed resources for poultry production in asia and the pacifik regional in energy sources. World's Poultry Science Journal Vol. 47. 213 - 218.

Stell, R. G. D. dan J. H Torrie. 1991. Prinsip dan Prosedur Statistika Suatu Pendekatan Biometrik. PT. Gramedia Jakarta.

Tilman, A. D., S. Reksohadi Projo, S., Prawirokusumo, dan Lebdo Soekojo. 1998. Ilmu Makanan Ternak Dasar. Gadjah Mada University Press. Yogyakarta

Yudono, B. F. Oesman, dan Hermansyah. 1996. Komposisi asam lemak sekam dan dedak padi. Majalah Sriwijaya. Vol. 32. No. 2. 8-11

Zuprizal. 2000. Komposisi kimia dedak padi sebagai bahan pakan lokal dalam ransum ternak. Buletin Peternakan Edisi Tambahan. 282 - 286 
ISSN 1978 - 3000

Jurnal Sain Peternakan Indonesia Vol. 2, No 1, Januari - Juni 2007 